\title{
Marka Aşkının Öncülleri ve Sonuçları: Doğu Karadeniz Bölgesinde Bir Uygulama $^{1}$
}

\author{
Emel YILDIZ*, Reyhan GÜNAYDIN**
}

\section{ÖZ}

Önceleri tüketiciler istek ve ihtiyaçlarını sınırlı seçenekler arasından karşılarken günümüzde teknolojinin gelişmesinin getirdiği erişim kolaylığı ile seçeneklerin sayısı artmıştır. Bu nedenle, markaya karşı duygusal ve tutkulu bağı ifade eden marka aşkı kavramı önem kazanmaya başlamıştır. Bu araştırmanın amacı; marka çağrışımları, marka güveni, marka farkındalığı, marka imajı ve algılanan kalitenin marka aşkı üzerindeki etkilerini; Marka aşkının da marka sadakati ve kulaktan kulağa pazarlama davranışı üzerindeki etkilerinin belirlenmesidir. Araştırmanın ana kütlesi Doğu Karadeniz Bölgesinde yaşayan ve Türkiye'de faaliyet gösteren ünlü bir elektronik markası müşterilerinden oluşmaktadır. Kolayda örnekleme yöntemi ile elde edilen 400 tüketiciye yüz yüze anket yöntemi uygulanmıştır. Verilerin geçerlilik ve güvenilirliklerini test etmek için faktör analizi ve cronbach alfa yöntemi uygulanmışır. Araştırma hipotezleri yapısal eşitlik modellemesi ile test edilmiştir. Araştırma sonucunda marka çağrışımları, marka güveni, marka farkındalığı, marka imajı ve algılanan kalitenin marka aşkını, marka aşkının da marka sadakati ve kulaktan kulağa pazarlama davranışını pozitif yönlü etkilediği tespit edilmiştir.

Anahtar Kelimeler: Marka Aşkı, Marka İmajı, Marka Farkındalığı, Marka Sadakati, Kulaktan Kulağa Pazarlama

JEL Sinıflandırması: M30, M31

\section{Antecedenets and outcomes of brand love: An application in the Eastern Black Sea Region}

\begin{abstract}
Previously, consumers have met their request and needs through limited choices, but nowadays the number of options has increased with the ease of access provided by the development of technology. Therefore, the concept of brand love, which expresses the emotional and passionate bond against the brand, has started to gain importance. The purpose of this research is to determine the effects of brand associations, brand trust, brand awareness, brand image and perceived quality on brand love and effects of brand love on brand loyalty and word-of-mouth marketing. The main mass of the research consists of consumers who live in the Eastern Black Sea Region and are the customers of famous electronic brand operating in Turkey. Face-to-face survey was applied to 400 consumers which were obtanined by convenience sampling method. Factor analysis and cronbach's alpha method were used to test the validity and reliability of the data. Research hypotheses were tested by structural equation modeling. As a result of the research, it was determined that brand associations, brand trust, brand awareness, brand image and perceived quality affect brand love and brand love affect brand loyalty and word-of-mouth positively.
\end{abstract}

Keywords: Brandlove, Brand Image, Brand Awareness, Brand Loyalty Word-of-Mouth

JEL Classification: M30, M31

Geliş Tarihi / Received: 06.03.2019 Kabul Tarihi / Accepted: 30.05.2019

1 Bu çalışma 27 - 29 Eylül 2018 tarihleri arasında Uluslararası Marka ve Marka Kent Kongresinde bildiri olarak sunulmuştur.

* Dr. Öğr. Üyesi, Gümüşhane Üniversitesi, İ̈BF, İnsan Kaynakları Yönetimi Bölümü, emel.yildiz@yahoo.com, ORCID: 0000-0001-7190-593X.

** ORCID: 0000-0002-7868-5076. 


\section{GİRİş}

Teknolojinin gelişmesi, pazarın büyümesi, rekabetin artması gibi etmenler işletmelerin yeni müşteri kazanma ve var olan müşterilerini elde tutmak için yeni yöntemler bulmalarını gerekli kılmıştır. $\mathrm{Bu}$ sebeple işletmeler sahip olduğu markalarını, diğer markalardan öne çıkarmak için çeşitli çalışmalar yapmaktadırlar. Bu çalışmalardan biri olan marka aşkı kavramı, tüketicinin kullandığ 1 markaya karşı bir aşk duygusu hissetmesinden geçmektedir. Marka aşk1 kavramı son zamanlarda ortaya çıkan ve popülerliği giderek artan bir kavram olarak gözükmektedir (Roy vd., 2013: 326). Bu kavram kişiler arası ilişkilerden esinlenerek ortaya atılmıştır ve tüketicinin kişiler arası ilişkilerde olduğu gibi bir markaya karşı geliştirdiği tutku ve bağl1lı̆̆1 esas almaktadır (Halilovic, 2013: 7).

Bir markaya karşı aşk duyan tüketicinin, o markayı tekrar satın alma davranışına yöneldiği gözlemlenmektedir. Böylelikle markaya duyulan aşk ile işletmelerin mevcut müşterisini kaybetme riski ortadan kalkacağı düşünülmektedir. Bu bağlamda işletmelere marka aşk1 oluşturma konusunda büyük sorumluluklar düşmektedir. Tüketicide marka aşk1 oluşturmadan önce marka ile ilgili diğer kavramlara da dikkat edilmesi gerekmektedir. Nitekim marka kavramı bir bütündür ve markasını daha iyi bir konuma taşımak isteyen işletmeler için büyük önem arz etmektedir. Marka aşkı kavramını oluşturmak için öncelikle tüketicide marka ile ilgili diğer kavramların oluşturulması gerekmektedir.

Marka aşkına yönelik literatür incelendiğinde pek çok çalışmanın varlığından bahsetmek mümkündür. İlgili çalışmalara kuramsal çerçeve kısmında detaylı bir şekilde yer verilmiş olup, pek çok araştırmacının (Andersen, 2011; Özbek ve diğerleri, 2017; Albert ve Merunka, 213; Aydın, 2017; Slaiman ve Lubis, 2015; Önen, 2018; Yang, 2010) marka çağrışımları, marka farkındalığı, marka güveni, algılanan kalite ve marka imajının marka aşkı üzerindeki etkisini, marka aşkının da sadakat ve kulaktan kulağa pazarlama üzerindeki etkisini (Maisam ve Mahsa, 2016; Tekbıyık, 2017; Sallam ve Wahid, 2015; Meisenzahl, 2017; Sta ve diğerleri, 2018) ayrı ayrı ölçmeye çalıştığı görülmektedir. Tüm değişkenlerin tek bir modelde incelendiği çalışmaların eksikliği literatürde bir boşluk olarak görülmektedir. Bu bağlamda, bu çalışmada yapısal eşitlik modeli analizinden faydalanılarak marka çağrışımları, marka güveni, marka farkındalığı, marka imajı ve algılanan kalitenin marka aşkı üzerindeki etkileri, marka aşkının da sadakat ve kulaktan kulağa pazarlama davranışı üzerindeki etkileri araştırılmaktadır. Bu çalışmanın uygulamacılara ve marka yöneticilerine, tüketicide markaya karşı bağlılık oluşturma ve markayı diğer tüketicilerle paylaşmasını sağlama açısından marka aşkının önemini anlamaları ve tüketicilerde marka aşkı duygusunu oluşturmak için nelere önem vermeleri ve hangi stratejileri uygulamaları gerektiği noktasında katkı sağlayacağı düşünülmektedir.

\subsection{Kavramsal ve Kuramsal Çerçeve}

Marka çağrışımı, tüketicinin bir markayla ilgili zihninde canlandırdığı 'şey' olarak tanımlanarak aynı zamanda markanın 'kalbi ve ruhu' şeklinde nitelendirilmektedir (Aaker, 1991: 109). Başka bir tanımla marka çağrışımları, tüketicilerin zihninde markaya ait olan bilgiler ve markanın anlamını içermektedir (Keller, 2003: 66). Andersen (2011) çalışmasında marka çağrışımları ile marka sevgisi arasında anlamlı ve olumlu bir ilişki olduğunu belirlemiştir. Bu bulguya paralel şekilde Vahap Önen (2018)'in yaptığı çalışmada İstanbul'daki Starbuckscafe müşterileri ile anket gerçekleştirilmiş ve analizler sonucunda çağrışımları ile marka aşkı arasında pozitif yönde bir ilişki olduğu tespit edilmiştir.

Literatürdeki bu bulgulardan hareketle, H1 hipotezi aşağıdaki gibi oluşturulmuştur.

$\mathrm{H}_{1}$ : Marka çağrışımları marka aşkını pozitif yönde etkiler. 
Güvenin oluşabilmesi için, bir tarafın karşısındaki tarafin güvenilir olduğuna emin olması ve itaat etme isteğine denmektedir (Moorman vd., 1993: 82). Marka güveni, müşterinin bir markayla ilgili verilen sözlerin gerçekleştirileceğine olan inancını kapsamaktadır (Chaudhuri ve Holbrook, 2001: 83). Başka bir tanımda marka güveni, bir markanın tercih edilme niyetinden önce oluşan markaya olan inançtır (Swaen ve Chumpitaz, 2008: 13). Marka güveninin marka aşkının oluşmasında önemli bir etken olduğu ifade edilmektedir (Albert ve diğerleri, 2008) Bu ifadeyi destekler nitelikte Merunka (2013) çalışmasında marka güveni ve marka aşkı arasında güçlü bir ilişki olduğu, Albert ve Merunka (2013)'nın 1505 tüketici ile gerçekleştirdiği araştırmada marka güveni ve marka kimliği ile marka aşkı arasında; marka taahhütü, ağızdan ağıza pazarlama ve daha yüksek fiyat ödeme eğilimi ile marka aşkı arasında güçlü ilişkiler olduğu ortaya çıkmıştır. Turgut (2014) çalışmasında marka güveninin marka aşkını doğrudan etkilediğini belirlemiştir. Selma Kalyoncuoğlu (2017)'nun çalışmasında Türkiye'de faaliyet gösteren Starbucks kahve dükkanına giden 378 tüketici ile internet üzerinden anket gerçekleştirilmiştir. Çalışma sonucunda marka aşkının markaya duyulan güven ile marka sadakati arasındaki ilişkide aracı etkisinin olduğu ortaya koyulmuştur. Özbek ve diğerleri (2017) banka müşteriler üzerinde gerçekleştirdikleri araştırmalarında güvenin marka aşkı üzerinde pozitif etkisi olduğunu belirlemişlerdir. Literatürdeki bu bulgulardan hareketle, H1 hipotezi aşağıdaki gibi oluşturulmuştur.

Literatürdeki bu bulgulardan hareketle, $\mathrm{H} 2$ hipotezi aşağıdaki gibi oluşturulmuştur.

$\mathrm{H}_{2}$ : Marka güveni marka aşkını pozitif yönde etkiler.

Tüketiciler çeşitli alternatifler arasından bir marka seçimi yaparken etkili olan (Keskin ve Yıldız, 2010: 241) marka farkındalığı, bir markanın tüketicinin hafızasında yarattığı etki olarak ifade edilmektedir (Aaker, 1996: 7). Bir başka tanıma göre marka farkındalığı, markanın tüketicinin hafızasında yer ettiği iyi ve kötü bilgilerin tamamından oluşmaktadır (Valkenburg ve Bujizen, 2005: 457). Marka farkındalığı ve marka aşkı arasındaki etkileşimi incelediği çalışmasında Aydın (2017) Muş ilinde bulunan 385 tüketiciye anket uygulamış ve elde edilen veriler yapısal eşitlik ve process analizleri kullanılarak test edilmiştir. Analiz sonuçlarına göre; marka güveni, marka farkındalığı ve benlik imaj uyumunun marka bağlılığı üzerine olan etkilerinde marka aşkının aracı etkisinin varlığı ortaya çıkmıştır. Ayrıca marka güveninin marka bağlılığına etkisinde marka aşkının aracı rolünün etkisinin fazla olduğu gözlenmiştir.

Literatürdeki bu bulgulardan hareketle, H3 hipotezi aşağıdaki gibi oluşturulmuştur.

$\mathrm{H}_{3}$ : Marka farkındalığı marka aşkını pozitif yönde etkiler.

Marka imajı, belirli bir marka hakkında benimsenen algılamaların tümüdür (Kotler, 1988: 197). Daha geniş kapsamda marka imajı, tüketicilerin zihninde veya duygularında marka ile ilgili oluşan tüm unsurlardır (Odabaş1 ve Oyman, 2007: 369). Ismail ve Spinelli (2012)' nin çalışmasında 250 lisans öğrencisiyle anket çalışması gerçekleştirilmiştir. Analiz sonucunda marka kişiliğinin (heyecan boyutu) marka aşkını olumsuz, kulaktan kulağa pazarlamayı ve marka imajını olumlu etkilediği gözlemlenmiştir. Ayrıca marka imajının marka aşkının belirleyicisi olduğu ve olumlu etkilediği ortaya çıkmıştır. Benzer şekilde Fournier (1998), Aaker (1997), Ünal ve Aydın (2013), Anggraeni ve Rachmanita (2015), Slaiman ve Lubis (2015), Maisam ve Mahsa (2016) çalışmalarında marka imajının marka aşkı üzerinde olumlu yönde bir etkiye sahip olduğunu belirlemişlerdir. Skoog ve Söderström (2015) çalışmalarında marka imajının marka aşkının belirleyicisi olduğu sonucuna ulaşmışlardır.

Literatürdeki bu bulgulardan hareketle, $\mathrm{H} 4$ hipotezi aşağıdaki gibi oluşturulmuştur.

$\mathrm{H}_{4}$ : Marka imajı marka aşkını pozitif yönde etkiler.

Algılanan kalite, tüketicilerin bir marka ile ilgili soyut algılamalarını içermektedir. Markanın tüketici nezdindeki performansının genel ölçütüdür (Aaker, 2009: 107). Franzen' e 
göre algılanan kalite tüketicinin hafizasında meydana gelen bir süreçtir. Tüketicinin hafizasında toplanan bilgilerin belli aşamalardan geçmesiyle oluşmaktadır (Giep, 2002: 57). Algılanan kalite tüketilerde marka aşkı duygusunun oluşmasında etkili olmaktadır (Othman ve diğerleri, 2017: 771). Önen (2018) çalışmasında İstanbul'daki Starbuckscafe müşterileri ile gerçekleştirdiği anketten elde edilen verileri doğrusal regresyon analizi ile test etmiştir. Analizler sonucunda algılanan kalite ile marka aşkı arasında anlamlı ve pozitif yönde bir ilişki olduğu belirlenmiştir. Yang (2010)'ın çalışmasında Çin'de 251 üniversite öğrencisi ile anket gerçekleştirilmiştir. Analiz sonuçlarına göre algılanan kalite, marka aşkı üzerinde anlamlı ve olumlu bir etkiye sahiptir.

Literatürdeki bu bulgulardan hareketle, H5 hipotezi aşağıdaki gibi oluşturulmuştur.

$\mathrm{H}_{5}$ : Algılanan kalite marka aşkını pozitif yönde etkiler.

Marka aşkı kavramı ilk olarak Sternberg (1986)' in kişilerin birbirine duyduğu aşkı anlattığı 'Üçgen Aşk Teorisi' nden yola çıkılarak ortaya atılmıştır (Shimp ve Madden, 1988: 163). Aşk, bir kişinin diğer bir kişiden duygusal olarak etkilenmesi ve o kişiye karşı güçlü hisler beslemesi olarak tanımlanmaktadır (dictionary.cambridge.org). Marka aşk1 ise tüketicinin herhangi bir markadan memnun olmasıyla beraber markaya karşı geliştirdiği tutku, bağl1lık ve tüm duygusal hisleri şeklinde tanımlanmaktadır (Carroll ve Ahuvia, 2006: 81).

Marka aşkı kavramı Saatchi\& Saatchi'nin CEO'su olan Kevin Roberts ile pazarlama dünyasına girmiş bir kavramdır. Roberts'a göre marka aşkının oluşabilmesi için üç boyutun varlığı gerekmektedir. Bu boyutlar; gizem, keyif ve yakınlık boyutlarıdır ( Roberts, 2004: 77). Marka aşkı, zihinsel bir model olup uzun süreli birden fazla biliş, duygu ve davranışları içerisinde barındırmaktadır (Ahuvia vd., 2012: 5). Marka aşkı, marka ile tüketici arasında ki tutkulu, samimi bir ilişki olup amaçlı ve karşılıklı bir kavram olarak nitelendirilmiştir (Keh vd., 2007: 84). Başka bir tanımda ise marka aşkı 'tüketici ve marka arasındaki yoğun duygusal ilişkiler' şeklinde tanımlanmıştır (Langer vd., 2015: 1). Marka aşkı kavramı 11 boyut altında toplanmaktadır; bunlar 'tutku, ilişkinin süresi, benlik uyumu, hayaller, anılar, memnuniyet, sempati, eşsizlik, güzellik, güven ve etkinin beyan edilmesi' şeklindedir (Albert vd., 2008: 1071). Başka bir çalışmada ise marka aşkı boyutları 'tutkulu davranış, kendini marka ile denk düşünme, duygusal bağlılık, markanın pazardan çekilmesi düşüncesinden dolayı endişe duyma, uzun ilişki, markaya karşı güven ve olumlu tutum' şeklinde ifade edilmektedir (Batra vd., 2012: 13). Bunlara ek olarak tüketicinin bir markaya karşı güçlü bir marka aşkına sahip olduğunda bazı boyutlar ortaya çıkmaktadır. Bu boyutlar; markanın kalitesi ve iyi fiyatıyla ilgili algılar, marka ile uzun süreli bir ilişki sözü, markanın sağladığı psikolojik iyilik ve ilgidir (Albert vd., 2008: 1072).

Marka sadakati, tüketicinin bir markayı değiştirmeyle ilgili gerçekleşen dış etkenlerin olmasına rağmen, o markayı tekrar satın almasıdır (Oliver, 1999: 34). Marka sadakati başka bir deyişle, tüketicinin çeşitli markalardan birini tercih etmesi ve satın almaya devam etmesidir. Bir marka hakkında karar verme, değerlendirme gibi tüm psikolojik süreçleri içine almaktadır (Jacoby ve Chestnut, 1978: 80).

Marka sadakati ile ilgili yapılan çalışmaların genelinde, davranışsal sadakat ve tutumsal sadakat şeklinde iki boyut olarak ele alınmaktadır (Jacoby ve Kyner, 1973: 3; Dick ve Basu, 1994: 100). Davranışsal sadakat, tercih edilen markayı tekrar satın alma şeklinde oluşurken, tutumsal sadakat devamlı satın almaya bağlı güçlü bir bağl1lı derecesi şeklinde tanımlanmaktadır (Chaudhuri ve Holbrook, 2001: 82). Aşkın ve İpek (2016)' in çalışmasında otomobil markaları ile deneyim yaşamış olan 178 kişi ile anket gerçekleştirilmiştir. Anket sonucu elde edilen veriler yapısal eşitlik ile analiz edilmiştir. Analiz sonuçlarına göre, marka aşkının marka deneyimi ile marka sadakati arasında tam aracı etkisi olduğu ortaya çıkmıştır. Özyer (2015) çalışmasını lisans ve lisansüstü eğitim göre 272 kişi ile gerçekleştirmiştir. Çalışma 
sonucunda marka aşkının, marka sadakati üzerinde etkili olduğu sonucuna varılmıştır. Benzer şekilde, Carroll ve Ahuvia (2006), Filho ve diğerleri (2010), Tekbıyık (2017), Bergkvist ve diğerleri (2010), Sallam ve Wahid (2015), Meisenzahl (2017), Sta ve diğerleri (2018), Acheampong (2018), Gomez ve Perez (2018) marka aşkının marka sadakatini pozitif yönde etkilediğini ifade etmişlerdir. Hwang ve Kandampully (2012)' nin çalışmasında 120 lisans öğrencisine anket uygulanmıştır. Yapısal eşitlik analizi sonuçlarına göre, marka aşkı ve duygusal bağın, marka sadakati üzerinde etkisi olduğu ortaya çıkmıştır. Skoog ve Söderström (2015) çalışmalarında marka aşkının marka sadakatinin belirleyicisi olduğu sonucuna ulaşmışlardır.

Literatürdeki bu bulgulardan hareketle, H6 hipotezi aşağıdaki gibi oluşturulmuştur.

$\mathrm{H}_{6}$ : Marka aşk1 marka sadakatini pozitif yönde etkiler.

Kulaktan kulağa pazarlamanın tüketiciler üzerindeki etkilerine ilişkin ilk çalışmalar John Arndt tarafindan yapılmıştır (Arndt, 1967). Silverman' a göre kulaktan kulağa pazarlama tüketicilerin bir marka veya ürüne sahip olduktan sonra onunla ilgili yaşadığ 1 deneyimleri diğer tüketiciler ile paylaşması ve bilgi alışverişinde bulunmasıdır (Silverman, 2001: 9). Bir işletmenin ürün veya hizmetleriyle ilgili ya da işletmenin faaliyetleri hakkında bir müşteriden diğer potansiyel müşterilere iletilen mesajlar olarak da tanımlanabilen (Özkan ve Yıldız, 2015: 362) kulaktan kulağa pazarlama, tüketicilerin diğer tüketicilerle firma, marka gibi bir hedef nesne ile ilgili konuşması ve bu hedef nesne ile ilgili bilgiyi (Yıldız ve Tehci, 2014: 444) onlara aktarmasıdır. Tüketicilerin kulaktan kulağa pazarlamayı tercih etmesinin sebebi arkadaşlarına olan güvenlerinin daha çok olmasından kaynaklanmaktadır (Lee ve Youn, 2009: 473). Kulaktan kulağa pazarlamanın gerçekleşmesi için sekiz unsur vardır. Bunlar; kaynak, kodlama, mesaj, kod açma, alıc1, iletilen tepki, geri bildirim ve gürültü şeklinde sıralanabilmektedir (Kotler vd., 2005: 728-729).

Kulaktan kulağa pazarlama, olumlu ve olumsuz olmak üzere iki başlık altında toplanmaktadır. Olumlu kulaktan kulağa pazarlama, marka veya ürünle ilgili olumlu deneyimleri paylaşma, önerme ve ikna ile oluşmaktadır (Çaylak ve Tolon, 2013: 4). Olumsuz kulaktan kulağa pazarlama, tüketicinin marka ile ilgili olumsuz deneyimleri paylaşma, markayı kötüleme ve markayı şikayet etme davranışlarını kapsamaktır (Anderson, 1998: 6). Wallace, Buit ve de Chernatony (2014)'nin çalışmalarında 256 facebook kullanıcısı ile anket yapılmıştır. Elde edilen veriler yapısal eşitlik analizi kullanılarak test edilmiştir. Analiz sonuçlarına göre marka aşkının kulaktan kulağa pazarlama ve marka kabulü üzerinde olumlu etkisi bulunmaktadır. Merunka (2013) marka aşk1 ile kulaktan kulağa pazarlama davranışı arasında güçlü bir ilişki olduğunu belirlemiştir. Özyer (2015) ve Filho ve diğerleri (2010) marka aşkının kulaktan kulağa pazarlama davranışını artırdığını belirlemiştir. Carroll ve Ahuvia (2006)' nın çalışmasında 21 yaş üstü, 334 kişi ile anket gerçekleştirilmiştir. Anket sonuçlarından elde edilen bilgiye göre marka aşkının kulaktan kulağa pazarlama üzerinde etkisi olduğu sonucuna ulaşılmıştır. Tekbıyık (2017)' in çalışmasında 210 twitter kullanıcısı ile çalışma gerçekleştirilmiştir. Çalışma sonucunda marka aşkının; ağızdan ağıza pazarlama ve elektronik ağızdan ağıza pazarlama üzerinde olumlu etkileri olduğu belirlenmiştir. Batra ve diğerleri (2012), Fetscherin (2014), Anggraeni ve Rachmanita (2015), Maisam ve Mahsa (2016) marka aşkının kulatan kulağa pazarlama davranışı üzerinde olumlu yönde bir etkiye sahip olduğunu belirlemişlerdir. Niyomsart ve Khamwon (2016)In çalışmalarında Asya havayolları müşterilerine yüzyüze anket uygulanmış ve marka aşkının marka sadakati aracılığıyla kulaktan kulağa pazarlama davranışını dolaylı olarak etkilediği tespit edilmiştir.

Literatürdeki bu bulgulardan hareketle, $\mathrm{H}_{7}$ hipotezi aşağıdaki gibi oluşturulmuştur.

$\mathrm{H}_{7}$ : Marka aşkı kulaktan kulağa pazarlamayı pozitif yönde etkiler. 


\section{ARAŞTIRMANIN AMACI, METODOLOJISİ VE BULGULARI}

\subsection{Araștırmanın Amacı}

$\mathrm{Bu}$ çalışmada marka çağrışımları, marka güveni, marka farkındalığı, marka imajı ve algılanan kalitenin marka aşkına etkileri ve marka aşkının da marka sadakati ve kulaktan kulağa pazarlama davranışı üzerindeki etkileri belirlenmeye çalışılmıştır.

\subsection{Araştırmanın Metodolojisi}

\subsection{1. Örnekleme Süreci}

Marka aşkının belirleyicileri ve sonuçlarının belirlenmesine yönelik bu çalışmada, 2018 yılında satış miktarı en fazla olan akı1lı telefon markası (www.log.com.tr) araştırmada kullanılacak elektronik cihaz markası olarak belirlenmiştir. Araştırmanın ana kütlesini Doğu Karadeniz Bölgesinde ikamet eden, belirlenen elektronik cihaz markasını kullanan tüketiciler oluşturmaktadır. Zaman ve maliyet kısıtı nedeniyle ana kütlenin tamamına ulaşmak mümkün olmadığından örneklem miktarının tespitinde tesadüfi olmayan örnekleme yöntemlerinden kolayda örneklem tercih edilmiştir. Araştırma kapsamında 416 tüketiciye anket uygulanmış, eksik ve hatalı anketler çıkarılarak 400 anket analize dâhil edilmiştir.

\subsubsection{Veri Toplama Yöntem ve Aracı}

Araştırmada yüz yüze anket yöntemi kullanılmıştır. Anket formu iki bölümden oluşmaktadır. İlk bölümde yer alan sorular araştırma modeli kapsamında incelenen değişkenlere yönelik sorulardan oluşmaktadır. İkinci kısım ise katılımcıların demografik özelliklerini belirlemeye yönelik sorulardan oluşmaktadır. Ankette 5'li likert ölçeği (1: Kesinlikle katılmıyorum, 2: katılmıyorum, 3: Karasızım, 4: Katılıyorum, 5: Kesinlikle Katıliyorum) kullanılmış olup katılımcılardan kendilerine uygun olan ifadeyi belirtmeleri istenmiştir.

\subsubsection{Araştırmanın Değişkenleri, Modeli ve Hipotezleri}

Araştırma kapsamında marka aşkı, marka güveni, algılanan kalite, marka sadakati, marka çağrışımları, marka farkındalığı, marka imajı ve kulaktan kulağa değişkenleri literatüre dayanarak belirlenmiştir. Araştırma kapsamında marka aşkı ölçeği (7 soru) (Carroll ve Ahuvia, 2006), Marka güveni (4 soru) (Chaudhuri ve Holbrook, 2001), Algilanan kalite (5 soru) (Yoo vd., 2000), Marka sadakati (4 soru) (Beatty ve Kahle, 1988; Chaudri ve Holbrook, 2001), Marka çağrışmları (3 soru) (Yoo ve Donthu, 1997), Marka farkındalığı (4 soru) (Oh, 2000; Yoo ve Donthu, 1997), Marka imaj1 (6 soru) (Kim vd., 2003; Lassar vd., 1995) ve Kulaktan kulağa pazalama (4 soru) (Harrison-Walker, 2001)'nın çalışmalarına dayanılarak oluşturulmuştur. 


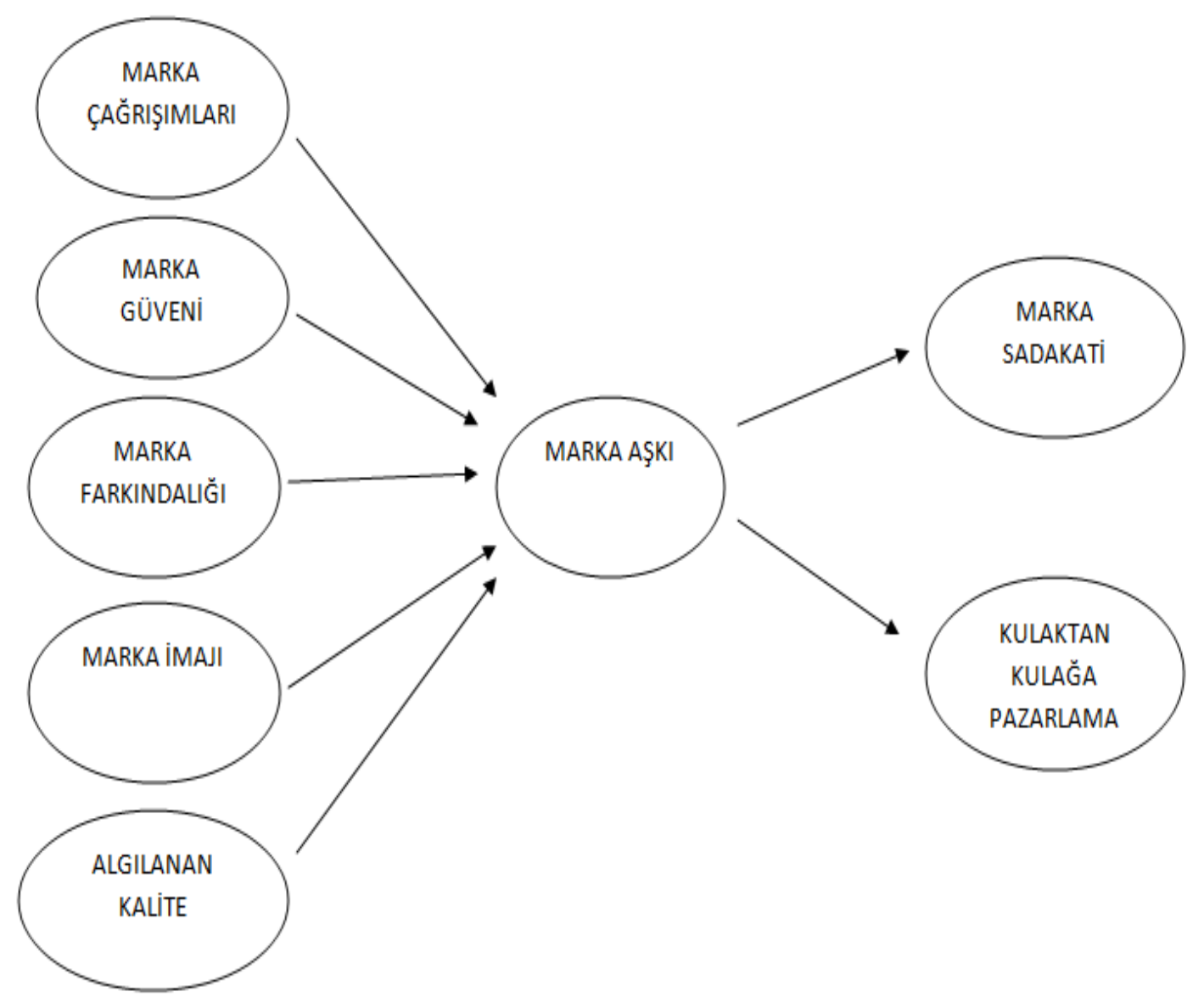

Şekil 1: Araştırma Modeli

\section{BULGULAR}

Bu bölümde ilk olarak araştırmaya katılan tüketicilerin cinsiyet, medeni durum, yaş, gelir, meslek, öğrenim durumu dağılımları belirlenmiş olup ardından geçerlilik güvenilirlik testi yapılmıştır. Daha sonra ise araştırma modelinden yer alan her bir değişkenin birbiri ile olan etkileşimini ölçmek amacıyla Yapısal Eşitlik Modeli sonuçlarına yer verilecektir. 


\subsection{Demografik Dağglıma İliş̧kin Bulgular}

\section{Tablo1: Araştırmaya Katılan Tüketicilerin Demografik Özellikleri}

\begin{tabular}{|c|c|c|c|c|c|}
\hline Cinsiyet & Frekans & Yüzde & Gelir & Frekans & Yüzde \\
\hline Kadın & 221 & 55,3 & 1500 TL ve altı & 140 & 35,0 \\
\hline Erkek & 179 & 44,8 & 1501 TL-3000 TL & 72 & 18,0 \\
\hline Toplam & 400 & 100,0 & 3001 TL-4500 TL & 67 & 16,8 \\
\hline $\begin{array}{c}\text { Medeni } \\
\text { Durum }\end{array}$ & Frekans & Yüzde & 4501 TL-6000 TL & 67 & 16,8 \\
\hline Evli & 116 & 29,0 & 6001 TL- 7500 TL & 17 & 4,3 \\
\hline Bekâr & 284 & 71,0 & 7501 TL ve üzeri & 37 & 9,3 \\
\hline Toplam & 400 & 100,0 & Toplam & 400 & 100,0 \\
\hline YAŞ & Frekans & Yüzde & Meslek & Frekans & Yüzde \\
\hline $\mathbf{1 7}$ ve altı & 11 & 2,8 & Serbest Meslek & 19 & 4,8 \\
\hline $\mathbf{1 8 - 2 8}$ & 252 & 63,0 & Esnaf & 9 & 2,3 \\
\hline $\mathbf{2 9 - 3 9}$ & 96 & 24,0 & Memur & 65 & 16,3 \\
\hline $\mathbf{4 0 - 5 0}$ & 27 & 6,8 & Sözleşmeli Personel & 21 & 5,3 \\
\hline $\mathbf{5 1 - 6 2}$ & 9 & 2,3 & Isçi & 18 & 4,5 \\
\hline 62 ve üzeri & 5 & 1,3 & Ev Hanımı & 11 & 2,8 \\
\hline Toplam & 400 & 100,0 & Öğrenci & 158 & 39,5 \\
\hline $\begin{array}{c}\text { Ŏğrenim } \\
\text { Durum }\end{array}$ & Frekans & Yüzde & Diğer & 99 & 24,8 \\
\hline İköğretim & 3 & 0,8 & Toplam & 400 & 100,0 \\
\hline Ortaöğretim & 27 & 6,8 & & & \\
\hline Ön Lisans & 50 & 12,5 & & & \\
\hline Lisans & 154 & 38,5 & & & \\
\hline Lisansüstü & 166 & 41,5 & & & \\
\hline Toplam & 400 & 100,0 & & & \\
\hline & & & & & \\
\hline
\end{tabular}

Tablo1' de görüldüğü gibi araştırmaya katılan kadınların oranı $(\% 55,3)$ iken, erkekler $(\% 44,8)$ ini oluşturmaktadır. Araştırmaya katılan tüketicilerden (\% 29)'u evli olup, (\%71)'si bekardır. Araştırmaya katılan katılımcıların büyük çoğunluğunun (\%63) 18-28 yaş aralığında olmasıyla beraber bunu (\%24) ile 29-39 yaş aralığ takip etmektedir. Öğrenim durumu olarak $(\% 41,5)$ ile en çok lisansüstü cevabı verilmiş olup bunu $(\% 38,5)$ ile lisans eğitimi takip etmektedir. Araştırmaya katılan tüketicilerin (\%35)'i 1500 TL ve altı ile ilk sırada yer almaktadır. Bunu (\%18) ile 1501 TL-3000 TL, daha sonra (\%16,8) ile 3001 TL- 4500 TL aras1 ve 4501 TL-6000 TL arası takip etmektedir. Meslek dağılımına bakıldığında ise $(\% 39,5)$ ile öğrencilerin en fazla olduğu ve $(\% 24,8)$ ile bunu diğer seçeneğinin takip ettiğgi gözükmektedir. Diğer seçeneğinde doktor, akademisyen vb. meslekler çoğunluktadır.

\subsection{Geçerlilik ve Güvenilirlik Analizi Bulguları}

Araştırmada kullanılan ölçeklerin güvenirliliklerini belirlemek amacıyla Cronbach Alfa analizinden, geçerliliklerini belirlemek amacıyla Faktör Analizinden yararlanılmıştır. Bu analizler sonucunda elde edilen veriler Tablo 2'de ki gibidir. 
Tablo2: Araştırmada Yer Alan Ölçeklerin Güvenirlilik ve Geçerlilik Analizi

\begin{tabular}{|c|c|c|c|c|c|c|c|c|}
\hline Ölçekler & Değişkenler & Alfa & Öz Değer & Varyans (\%) & KMO & Barlett Test & $\mathbf{P}$ & $\begin{array}{c}\text { Genel } \\
\text { Alfa }\end{array}$ \\
\hline \multirow{3}{*}{$\begin{array}{c}\text { Marka } \\
\text { Çağrışımla } \\
\text { rı }\end{array}$} & MÇ1 & 0,803 & \multirow[t]{3}{*}{2,306} & \multirow[t]{3}{*}{76,862} & \multirow[t]{3}{*}{0,730} & \multirow[t]{3}{*}{510,418} & \multirow[t]{3}{*}{0,000} & \multirow[t]{3}{*}{0,849} \\
\hline & MÇ2 & 0,790 & & & & & & \\
\hline & MÇ3 & 0,774 & & & & & & \\
\hline \multirow{4}{*}{$\begin{array}{l}\text { Marka } \\
\text { Güveni }\end{array}$} & MG1 & 0,915 & \multirow[t]{4}{*}{3,384} & \multirow[t]{4}{*}{84,603} & \multirow[t]{4}{*}{0,842} & \multirow[t]{4}{*}{1447,847} & \multirow[t]{4}{*}{0,000} & \multirow[t]{4}{*}{0,939} \\
\hline & MG2 & 0,921 & & & & & & \\
\hline & MG3 & 0,930 & & & & & & \\
\hline & MG4 & 0,915 & & & & & & \\
\hline \multirow{4}{*}{$\begin{array}{c}\text { Marka } \\
\text { Farkındalığ } \\
1\end{array}$} & MF1 & 0,918 & \multirow[t]{4}{*}{3,384} & \multirow[t]{4}{*}{84,595} & \multirow[t]{4}{*}{0,854} & \multirow[t]{4}{*}{1422,326} & \multirow[t]{4}{*}{0,000} & \multirow[t]{4}{*}{0,939} \\
\hline & MF2 & 0,918 & & & & & & \\
\hline & MF3 & 0,921 & & & & & & \\
\hline & MF4 & 0,925 & & & & & & \\
\hline \multirow{6}{*}{$\begin{array}{c}\text { Marka } \\
\text { İmajı }\end{array}$} & Mİ1 & 0,907 & \multirow[t]{6}{*}{4,402} & \multirow[t]{6}{*}{73,370} & \multirow[t]{6}{*}{0,866} & \multirow[t]{6}{*}{2221,940} & 0,000 & 0,924 \\
\hline & Mİ2 & 0,906 & & & & & & \\
\hline & Mİ3 & 0,901 & & & & & & \\
\hline & Mİ4 & 0,922 & & & & & & \\
\hline & Mİ5 & 0,907 & & & & & & \\
\hline & MÍ6 & 0,920 & & & & & & \\
\hline Algılanan & AK1 & 0,928 & 4,115 & 82,292 & 0,898 & 1934,473 & 0,000 & 0,946 \\
\hline Kalite & AK2 & 0,925 & & & & & & \\
\hline & AK3 & 0,932 & & & & & & \\
\hline & AK4 & 0,940 & & & & & & \\
\hline & AK5 & 0,942 & & & & & & \\
\hline Marka & MA1 & 0,941 & 5,442 & 77,737 & 0,902 & 3023,665 & 0,000 & 0,950 \\
\hline Aşkı & MA2 & 0,943 & & & & & & \\
\hline & MA3 & 0,941 & & & & & & \\
\hline & MA4 & 0,937 & & & & & & \\
\hline & MA5 & 0,942 & & & & & & \\
\hline & MA6 & 0,947 & & & & & & \\
\hline & MA7 & 0,948 & & & & & & \\
\hline Marka & MS1 & 0,882 & 3,226 & 80,646 & 0,795 & 1371,648 & 0,000 & 0,919 \\
\hline Sadakati & MS2 & 0,872 & & & & & & \\
\hline & MS3 & 0,918 & & & & & & \\
\hline & MS4 & 0,906 & & & & & & \\
\hline Kulaktan & KKP1 & 0,937 & 3,523 & 88,070 & 0,853 & 1767,843 & 0,000 & 0,954 \\
\hline Kulağa & KKP2 & 0,934 & & & & & & \\
\hline Pazarlama & KKP3 & 0,933 & & & & & & \\
\hline & KKP4 & 0,953 & & & & & & \\
\hline
\end{tabular}

Tablo 2' de görüldüğü gibi araştırmada kullanılan değişkenlerin güvenirlilik düzeyi şu şekildedir. Marka çağrışımları 0,849; Marka güveni ve marka farkındalığı 0,939, Marka imajı 0,924, Algılanan kalite 0,946, Marka aşkı 0,950, Marka sadakati 0,919, Kulaktan kulağa pazarlama 0,954'dür. Araştırmada yer alan ölçeklerin güvenirlilik düzeylerine bakıldığında çalışmanın oldukça güvenilir olduğu ve ölçekten herhangi bir değişkenin çıkarılması gerekmediği söylenebilmektedir.

Geçerlilik analizi sonuçlarına bakıldığında, ölçek değerlerinin $\mathrm{KMO}>0,5$ ve $\mathrm{p}<0,05$ olmasından dolayı, Faktör analizine uygun olduğu söylenebilmektedir. Marka çağrışımları maddeleri toplam varyansın \%76,862'ını açıklayan bir faktör altında toplanmış olup, öz değer $(2,306>1)$ olarak belirlenmiştir. Marka güveni maddelerinin toplam varyansin \%84,603'ünü açıklayan bir faktör altında toplanmış olup öz değerin $(3,384>1)$ olduğu görülmektedir. Marka farkındalığı maddelerinin toplam varyansın \%84,595'ini açıklayan bir faktör altında toplanmış olup öz değerin $(3,384>1)$ olduğu görülmektedir. Marka imajı maddelerinin toplam varyansın \%73,370' ini açıklayan tek bir faktör altında toplanmış olup öz değerin $(4,402>1)$ olduğu 
görülmektedir. Algılanan kalite maddelerinin toplam varyansın \%82,292'sini açıklayan tek bir faktör altında toplanmış olup öz değerin $(4,115>1)$ olduğu görülmektedir. Marka aşkı maddelerinin toplam varyansın \%77,737'sini açıklayan tek bir faktör altında toplanmış olup $(5,442>1)$ olduğu görülmektedir. Marka sadakati maddelerinin toplam varyansın \%80,646'sinı açıklayan tek bir faktör altında toplanmış olup (3,226>1) olduğu görülmektedir. Kulaktan kulağa pazarlama maddelerinin toplam varyansın \%88,070'ini açıklayan tek bir faktör altında toplanmış olup $(3,523>1)$ olduğu görülmektedir.

\subsection{Yapısal Eşitlik Analizi Bulguları}

Araştırmada kullanılan hipotezlerin testi için Yapısal Eşitlik Modellemesi kullanılmıştır.

Tablo 3: Araştırmada Yer Alan Model için Model Uyum Özeti

\begin{tabular}{|c|c|c|}
\hline Uyum Ölçütleri & Kabul Edilen & Model \\
\hline $\mathbf{X}^{2} / \mathbf{d f}$ & $<5.0$ & 3,31 \\
\hline NFI & $>0.9$ & 90.1 \\
\hline RFI & $>0.9$ & 88.8 \\
\hline IFI & $>0.9$ & 92.9 \\
\hline TLI & $>0.9$ & 91.9 \\
\hline CFI & $>0.9$ & 92.9 \\
\hline RMSEA & $<0.8$ & 0.76 \\
\hline
\end{tabular}

Kaynak: Baumgartner \& Homburg, 1996; Schermelleh-Engel \& Moosbrugger, 2003; Şimşek, 2007; Byrne, 2010; Gautam ve Kumar, 2011

Tablo 3' de belirtildiği üzere uyum indekslerinden çıkarılacak sonuçlar şu şekildedir $\left(\mathrm{x}^{2} / \mathrm{df}=3,31 ; \mathrm{NFI}=, 901 ; \mathrm{RFI}=, 888 ; \mathrm{IFI}=\right.$,929; TLI= ,919; CFI = 929; RMSEA $\left.=, 076\right) . \mathrm{Bu}$ sonuçlardan hareketle model ve veriler arasındaki uyumun güçlü olduğu söylenebilir. 


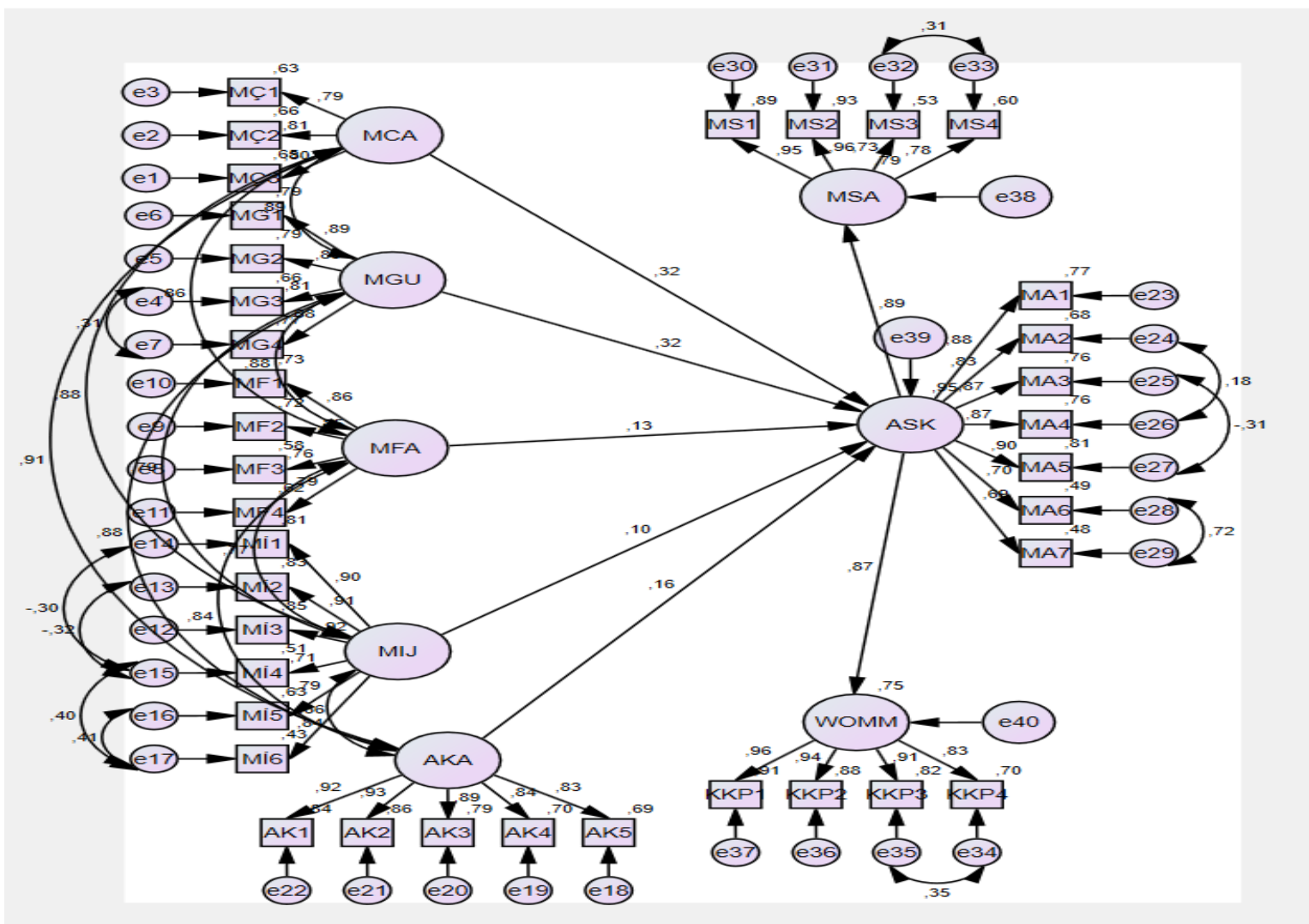

Şekil 2: Yapısal Eşitlik Modeli

Tablo 4: Araştırmada Yer Alan Modelin Değişskenlerinin Katsayıları

\begin{tabular}{|r|c|c|c|c|c|}
\hline Hipotezler & Değişkenler & Beta & S.E. & P & Sonuçlar \\
\hline H1 & MÇ-MA & .317 & .106 & .003 & Kabul edilmiştir. \\
\hline H2 & MG-MA & .321 & .063 & .001 & Kabul edilmiştir. \\
\hline H3 & MF-MA & .126 & .054 & .022 & Kabul edilmiştir. \\
\hline H4 & Mİ-MA & .104 & .044 & .037 & Kabul edilmiştir. \\
\hline H5 & AK-MA & .157 & .064 & .015 & Kabul edilmiştir. \\
\hline H6 & MA-MS & .886 & .046 & .001 & Kabul edilmiştir. \\
\hline
\end{tabular}

R2 Marka aşkl:0,947; R2 Sadakat:0,785; R2 Kulaktan kulağa pazarlama: 0,751

Tablo 4' de görüldüğü üzere; marka çağrışımları ( $\beta=, 317 ; \mathrm{p}<, 01)$, Marka güveni ( $\beta=$ $, 321 ; \mathrm{p}<, 01)$, Marka farkındalığ $(\beta=, 126 ; \mathrm{p}<, 05)$, Marka imaj1 $(\beta=, 104 ; \mathrm{p}<, 05)$, Algılanan kalite marka aşkını $(\beta=, 157 ; p<, 05)$, Marka aşk1 marka sadakatini $(\beta=, 886 ; p<, 01)$ ve kulaktan kulağa pazarlamayı $(\beta=, 866 ; \mathrm{p}<, 01)$ pozitif etkilemektedir. Bu sonuçlardan hareketle araştırmada kullanılan $\left(\mathrm{H}_{1}, \mathrm{H}_{2}, \mathrm{H}_{3}, \mathrm{H}_{4}, \mathrm{H}_{5}, \mathrm{H}_{6}, \mathrm{H}_{7}\right)$ hipotezlerinin kabul edildiği söylenebilmektedir.

Ayrıca kurulan yapısal eşitlik modelinde exojen değişkenlerin endojen değişkenler üzerindeki açıklama gücü $\left(\mathrm{R}^{2}\right)$ ele alınmıştır. Buna göre marka çağrışımları, marka güveni, marka farkındalığı, marka imajı ve algılanan kalite, marka aşkı değişkenindeki değişimin \%94,7'sini açıklamaktadır. Modelde yer alan diğer endojen değişkenler sadakat ve kulaktan kulağa pazarlama ise sırasıyla marka aşkı tarafından $\% 78,5$ ve $\% 75,1$ oranında açıklanmaktadır. 


\section{SONUÇ}

Bu çalışmada marka çağrışımları, marka güveni, marka farkındalığı, marka imajı ve algılanan kalitenin; marka aşkı üzerindeki etkileri incelenmiştir. Bunun yanında marka aşkının kulaktan kulağa pazarlama ve marka sadakati üzerindeki etkileri test edilmiştir.

Analizler sonucunda marka çağrışımları, marka güveni, marka farkındalığı, marka imajı ve algılanan kalitenin; marka aşkı üzerinde etkili olduğu ortaya çıkmış olup bunun yanında marka aşkının da marka sadakati ve kulaktan kulağa pazarlama davranışı üzerinde etkili olduğu sonucuna varılmıştır. Bu çalışma için birçok hipotez geliştirilmiş olup araştırma sonuçları şu şekildedir. Marka güveninin $(\beta=, 355 ; \mathrm{p}<, 05)$ marka aşk1 üzerinde en etkili faktör olduğu belirlenmiştir. Bundan hareketle kullandığı markaya karşı güven duyan tüketiciler de marka aşkı oluştuğu ifade edilebilir. Bu sonuca paralel şekilde literatürdeki çalışmalar marka güveni ile marka aşkı arasında güçlü ilişkiler olduğunu ve marka güveninin marka aşkını olumlu yönde etkilediğini belirlemişlerdir. (Merunka, 2013; Albert ve Merunka, 2013; Turgut, 2014; Kalyoncuoğlu, 2017; Özbek ve diğerleri, 2017). Marka aşkını olumlu etkileyen ikinci en önemli faktörün marka çağrışımları $(\beta=, 219 ; p<, 05)$ olduğu sonucuna varılmıştır. Bir diğer ifadeyle tüketicinin kullandığı marka ile ilgili kafasında canlanan her şey marka aşkını etkilemektedir. $\mathrm{Bu}$ bulguyu destekler nitelikte Önen (2018) ve Andersen (2011) marka çağrışımları ile marka aşkı arasında anlamlı ve olumlu yönde bir ilişki olduğunu ifade etmişlerdir. Marka aşkını etkileyen diğer faktörler ise önem sirasına göre ise marka imaj $(\beta=, 176 ; p<, 05)$, algilanan kalite $(\beta=, 161$; $\mathrm{p}<, 05)$ ve marka farkındalığıdır $(\beta=, 118 ; \mathrm{p}<, 05)$. Yapılan çalışmalarda da benzer şekilde Fournier (1998), Aaker (1997), Ünal ve Aydın (2013), Anggraeni ve Rachmanita (2015), Slaiman ve Lubis (2015), Maisam ve Mahsa (2016) çalışmalarında marka imajının marka aşkı üzerinde olumlu yönde bir etkiye sahip olduğunu belirlemişlerdir. Skoog ve Söderström (2015) çalışmalarında marka imajının marka aşkının belirleyicisi olduğu sonucuna ulaşmışlardır. Önen (2018) ve Yang (2010) algılanan kalitenin, Aydın (2017) marka farkındalığının marka aşkı üzerinde anlamlı ve olumlu bir etkiye sahip olduğunu tespit etmişlerdir. İşletme olarak sunduğunuz hizmet düzeyi ve bunun tüketiciler tarafından nasıl algılandığı marka aşk1 duygusunun oluşmasında önemlidir. Buna paralel bir marka, ürün ya da hizmet olarak tüketicinin zihninde nasıl bir imaja sahip olduğunuz ve tüketiciler tarafindan ne kadar bilindiğiniz/hatırlandığınız marka aşkını etkilemektedir.

Çalışma da ayrıca marka aşkının marka sadakatini $(\beta=, 864 ; \mathrm{p}<, 01)$ pozitif yönde etkilediği belirlenmiştir. Bir markaya karşı aşk duygusunun oluşmasıyla tüketici de o markaya karşı bağlılık oluşmaktadır. Bu bulguyu destekler nitelikte Carroll ve Ahuvia (2006), Filho ve diğerleri (2010), Tekbıyık (2017), Bergkvist ve diğerleri (2010), Sallam ve Wahid (2015), Meisenzahl (2017), Sta ve diğerleri (2018), Acheampong (2018), Gomez ve Perez (2018) marka aşkının marka sadakatini pozitif yönde etkilediğini ifade etmişlerdir. Skoog ve Söderström (2015) çalışmalarında marka aşkının marka sadakatinin belirleyicisi olduğu sonucuna ulaşmışlardır.

Tüketicilerde marka aşkının oluşması onları kulaktan kulağa pazarlama davranışına yöneltmektedir ( $\beta=, 847 ; \mathrm{p}<, 01)$. Yani tüketiciler o marka ile ilgili olumlu bilgi ve deneyimlerini eş, dost, akraba gibi çevresindeki insanlarla paylaşma davranış1 sergilemektedir. Literatürdeki çalışmalarda da (Merunka, 2013; Özyer, 2015; Filho ve diğerleri, 2010; Carroll ve Ahuvia, 2006; Tekbıyık, 2017; Batra ve diğerleri; 2012, Fetscherin; 2014, Anggraeni ve Rachmanita; 2015, Maisam ve Mahsa; 2016) bu bulguya paralel şekilde marka aşkının kulaktan kulağa pazarlama ile anlamlı bir ilişkiye sahip olduğunu ve marka aşkının kulaktan kulağa pazarlama üzerinde olumlu bir etkiye sahip olduğu belirlenmiştir. Bu çalışmadan hareketle belli bir markaya sahip olan işletmelerin, tüketici de markaya karşı bir aşk duygusu oluşturabilmesi için marka ile ilgili kavramları dikkate almaları gerektiğini söyleyebilmekteyiz. Marka aşkının oluşmasına yardımcı olacak; marka çağrışımları, marka farkındalığı, marka imajı, algılanan 
kalite, marka güveni kavramlarını dikkate almaları gerekmektedir. Bu kavramları tüketici nezdinde olumlu ve iyi tutabilirse tüketicilerde markaya karşı bir aşk duygusu gelişebilmektedir. Bunun yanında markanın terk edilmesini engelleyerek yeni müşteriler kazanmak için de marka aşkı kavramına ihtiyaç duyulmaktadır. Marka aşkının oluşumuyla var olan tüketicinin markaya sadık olması ve tekrar satın almanın devam etmesi sağlanabilmektedir. Bununla birlikte tüketicilerin diğer tüketiciler ile markayı paylaşması da yeni müşteri elde edilmesinde etkili olacaktır.

$\mathrm{Bu}$ çalışma gelecekteki çalışmalar için olanak sağlayan bazı sınırlılıklara sahiptir. $\mathrm{Bu}$ çalışmada elektronik cihaz kategorisinde belirli bir akıllı telefon markası incelenmiştir. Bu nedenle gelecekteki çalışmalarda farklı akıllı telefon markaları ya da farklı kategorideki markalar incelenerek analiz genişletilebilir. Bu çalışmada Doğu Karadeniz Bölgesinde ikamet eden tüketiciler incelenmiştir. Gelecekteki çalışmalarda araştırma modeli farklı dinamiklere sahip olan diğer bölge ve şehirlerde uygulanabilir.

\section{KAYNAKÇA}

Aaker, D. A. (1996). Building strong brand. Free Press.

Aaker, D. A. (1991). Managing brand equity: Capitalizing on the value of a brand name. New York: Free Press.

Aaker, D. A. (2009). Marka değeri yönetimi. (E. Orhanlı, Çev.) İstanbul: Mediacat .

Aaker, J. L. (1997). Dimensions of brand personality. Journal of Marketing, 34(3), 47-56.

Acheampong, Y. (2018). Examining the relatonship of brand love \& brand loyalty to luxury fashion brands in Russia. Master Thesis, Petersburg State University.

Ahuvia, A. C., Batra, R., \& Bagozzi, R. P. (2012). Brand love. Journal of Marketing, 76 (2), 1-16.

Albert, N., Merunka, D., \& Valette-Florence, P. (2008), When consumers love their brands: Exploring the concept and its dimensions, Journal of Business Research, 61(10), 1062-1075.

Albert, Noel., \& Merunka, Dwight. (2013). The role of brand love in consumer-brand relationships. Journal of Consumer Marketing, 30 (3), 258-266.

Andersen, H.S. (2011). Exploring brand associations' effect on (un)conscious brand liking. Master Thesis Cand.Merc.Kommunikation, Copenhagen Business School.

Anderson, E. W. (1998). Customer satisfaction and word-of- mouth. Journal of Service Research, 1(1), 5-17.

Anggraeni, A. \& Rachmanita (2015). Effects of brand love, personality and image on word of mouth; the case of local fashion brands among yound customers. Procedia-Social and Behavioral Sciences, 211, 442-447.

Arndt, J. A. (1967). Role of product- related conversations in the diffusion of a new product. Journal of Marketing Research, 4 (3), 291-5.

Aşkın, N. ve İpek, İ. (2016). Marka aşkının marka deneyimi ile marka sadakati arasındaki ilişkiye aracılık etkisi. Ege Akademik Bakış, 16(1), 79-94.

Aydın, H. (2017). Marka güveni, farkındalığı ve benlik imaj uyumunun marka bağlılığına etkisinde marka aşkının aracılık rolü. Ege Akademik Bakışı, 17(2), 281-294.

Batra, R., Ahuvia A. \& Bagozzi, R.P. (2012). Brand love. Journal of Marketing, 76(2), 1-16.

Baumgartner, H., \& Homburg, C. (1996). Applications of structural equation modeling in marketing and consumer research: A review. International Journal of Research in Marketing, 13(2), 139-161.

Beatty, S. E., \& Kahle, L. R. (1988). Alternative hierarchies of the attidu-behavior relationship: The impact of brand commitment and habit. Journal of the Academy of Marketing Science, 16(2), 1-10.

Bergkvist, L \& Larsen, T.B. (2010). Two studies of consequences and actionable antecedents of brand love. Journal of Brand Management, 17(7), 504-518. 
Byrne, B.M. (2001). Structural equation modeling with AMOS, EQS, and LISREL: Comparative approaches to testing for the factorial validity of a measuring instrument. International Journal of Testing, 1(1), 55- 86.

Carroll, B. A., \& Ahuvia, A. C. (2006). Some antecedents and outcomes of brand love. Marketing Letters, 17(2), 7989.

Chaudhuri, A., \& Holbrook, M. B. (2001). The chain of effects from brand trust and brand affect to brand performance: The role of brand loyalty. The Journal of Marketing, 81-93.

Çaylak, P., ve Tolon, M. (2013). Ağızdan ağıza pazarlama ve tüketicilerin ağızdan pazarlamayı kullanmaları üzerine bir araştırma. Gazi Üniversitesi İktisadi ve İdari Bilimler Dergisi, 15(3), 1-30.

Dick, A., \& Basu, K. (1994). Consumer loyalty: Toward on integrated conceptual framework. Journal of The Academy of Marketing, 22(2), 99-113.

Fetscherin, M. (2014). What type of relationship do we have with loved brands?. Journal of Consumer Marketing, 31(6/7), 430-440.

Filho, C.G., Monteiro, P.R.R. \& Souki, G.Q. (2010). The Impacts of Brand Love, Brand Equity in the Consumer's Loyalty and the Customer's Purchase Intentions: The Development and Testing of Alternative Models in the Automotive Sector. EnANPAD 2010.

Fournier, S. (1998). Consumers and their brands: developing relationship theory in consumer research. Journal of Consumer Research, 24(4), 343-73. http://dx.doi.org/10.1086/209515.

Gautam, V. \& Kumar, M. (2011). An empirical investigation of factors determining the consumers' choice of mobile service providers. Işletme Araştırmaları Dergisi, 3(4), 3-17.

Giep, F. (2002). Reklamların marka değerine etkisi. (F. Yalım, Çev.) İstanbul: Mediacat.

Gomez, M.C.O. \& Perez, W.G. (2018). Effects of brand love and brand equity on repurchase intentions of young consumers. Internatonal Review of Management and Marketing. 8(4), 7-13.

Halilovic, D. (2013). Crazy little thing called brand love! Exploring the influence of brand love on brand equity. Masters thesis, University of Twente . Enschede.

Harrison-Walker, L.J. (2001). The measurement of word-of-mouth communication and an investigation of service quality and customer commitment as potential antecedents. Journal of Service Research, 4(1), 60-75.

Hwang, J. \& Kandampully, J. (2012). The role of emotional aspects in younger consumer-brand relationships. Journal of Product \& Brand Management, 21(2), 98-108.

İslam, J. U. \& Rahman, Z. (2016). Examining the effects of brand love and brand image on customer engagement: An empirical study of fashion apparel brands. Journal of Global Fashion Marketing, 7(1), 45-59.

Ismail, A. R. \& Spinelli, G. (2012). Effects of brand love, personality and image on word of mouth: The case of fashion brands among young consumers. Journal of Fashion Marketing and Management: An International Journal, 16(4), 386-398.

Jacoby, J. \& Chestnut, R. W. (1978). Brand loyalty: Measurement and Management. New york: Wiley.

Jacoby, J. \& Kyner, D. B. (1973). Brand loyalty vs. repeat purchasing behavior. Journal Marketing Research, 10 (1), $1-9$.

Kalyoncuoğlu, S. (2017). Markaya duyulan güven ile marka sadakati ilişkisinde marka aşkının aracılık rolü: Starbucks markası üzerine bir araştırma. Journal of Tourism and Gatronomyt Studies, 5(4), 383-402.

Keh, H.T., Pang, J. \& Peng, S. (2007), Understanding and measuring brand love. Society for Consumer Psychology Conference Proceedings, Santa Monica.

Keller, K. L. (2003). Strategic brand management building, measuring, and managing brand equity. New Jersey: Prentice Hall Press.

Keskin D. H. \& Yıldız S. (2010). Tüketicilerin marka tercihlerinde etkili olan faktörler ile marka imajı'nın marka değeri üzerindeki etkileri: Trabzon örneği. Dumlupınar Üniversitesi Sosyal Bilimler Dergisi, 27, 239-254.

Kim, H.-b., Kim, W. G., \& A.An, J. (2003). The effect of consumer-based brand equity on firms' financial performance. Journal of Consumer Marketing, 20(4), 335-351.

Knox, S. \& Walker, D. (2001). Measuring and managing brand loyalty. Journal of Strategic Marketing, 9(2), 111-128.

Kotler, P. (1988). Marketing management: Analysis, planning and control. Englewood Cliffs: Prentice Hall. 
Kotler, P., Wong, V., Saunders, J., \& Armstrong, G. (2005). Principles of marketing (4th ed.). England: The Prentice Hall.

Langner, T., Schmidt, J., and Fischer, A. (2015), "Is it really love? A comparative investigation of the emotional nature of brand and interpersonal lrove”, Psychology \& Marketing, 32(6), 624-634.

Lassar, W., Mittal, B., \& Sharma, A. (1995). Measuring customer-based brand equity. Journal of Consumer Marketing , $12(4), 11-19$.

Lee, M., \& Youn, S. (2009). Electronic word of mouth. International Journal of Adversiting, 28(3), 479-499.

Maisam, S. \& Mahsa, R.d. (2016). Positive Word of mouth marketing: explaining the roles of value congruity and brand love. Journal of Competitiveness, 8(1), 19-37.

Meisenzahl, J. (2017). Correlation of brand experience and brand love using the example of flixbus. Master Thesis, Business Administration, Seinajok University of Applied Sciences.

Merunka, D. (2013). The role of brand love in consumer-brand relationships. Journal of Consumer Marketing, 1-20.

Moorman, C., Deshpande, R., \& Zaltman, G. (1993). Factors affecting trust in market research relationships. Journal of Marketing, 81-101.

Niyomsart, S. \& Khamwon, A. (2016). Brand love, brand loyalty and Word of mouth: A case of airasia. Conference of the International Journal of Arts \& Sciences, 09(01), 263-268.

Odabaşı, Y. ve Oyman, M. (2007). Pazarlama iletişimi yönetimi (Cilt 7). İstanbul: Mediacat Yayınları.

Oh, H. (2000). The effect of brand class, brand awareness and price on customer value and behavioral intentions. Journal of Hospitality an Tourism Research, 24(2), 133-162.

Oliver, R. L. (1999). Whence customer loyalty. Journal of Marketing, 63, 33-44.

Othman, M., Kamarohim, N. \& Nizam, F.M. (2017). Brand credibility, perceived quality and perceived value: A study of customer satisfaction. Int.Journal of Economcs and Management, 11(S3), 763-775.

Önen, V. (2018). Marka değerinin marka aşkına etkisinin incelenmesi: Starbucks cafe örneği. Avrasya Sosyal ve Ekonomi Araştırmaları Dergisi, 5(1), 49-63.

Özbek, V., Yıldırım-Kutbay, A., Doğan, Ö. ve Külahlı, A. (2017). Marka aşkının öncülleri: Banka müşterileri üzerinde bir araştırma. Global Business Research Congress, 24-25 Mayıs, İstanbul.

Özkan E., Yıldız S. (2015). Müşteri sadakati ile ağızdan ağıza iletişimin tüketici satın alma davranışlarına etkisi: elektronik eşya sektöründe bir uygulama. Uluslararası İktisadi ve İdari Íncelemeler Dergisi, 8(15), 359-379.

Özyer, G. N. (2015). Marka aşkının marka sadakati ve ă̆ızdan ă̆ıza pazarlamaya etkisi: Pilot bir araştırma. Marmara Üniversitesi Sosyal Bilimler Enstitüsü İşletme Anabilim Dalı Yüksek Lisans Tezi . İstanbul.

Roberts, K. (2004). Lovemarks: The future beyond brands. New York: Power House Books.

Roy, S. K., Eshghi, A., \& Sarkar, A. (2013). Antecedents and consequences of brand love. Journal of Brand Management, 20(4), $325-332$

Sallam, M.A. \& Wahid, N.A. (2015). The effects of satisfaction and brand identification on brand love and brand equity outcome: the role of brand loyalty. International Journal of Economics, Commerce and Management, 3(2), 113.

Schermelleh-Engel, K., \& Moosbrugger, H. (2003). Evaluating the fit of structural equation models: Tests of significance and descriptive goodness-of-fit measures, Methods of Psychological Research Online, 8(2), 23-74.

Shimp, T. A., \& Madden, T. J. (1988). Consumer-object relations: a conceptual framework based analogously on sternberg's triangular theory of love. Advances in Consumer Research, 15(1), 163-168.

Silverman, G. (2001). The secrets of word of mouth marketing. Newyork: American Management Association.

Skoog, M. \& Södeström, M. (2015). Antecedents and outcomes of brand love: A qualitative study within the swedish clothing industry. Thesis, Umeå School of Business and Economics, Umea University.

Slaiman, Y. \& Lubis, P.H. (2015). The role of brand love as mediation factor toward customer loyalty. Aceh International Journal of Social Sciences, 4(1), 68-73.

Sta,N., Abbasi, R. \& Elfidha C. (2018). The effect of brand love on brand performance: the role of brand loyalty. Journal of Business and Management Research, 11, 314-324. 
Swaen, V., \& Chumpitaz, R. C. (2008). Impact of corporate social responsibility on consumer trust. Recherce at Applications en Marketing, 23(4), 7-33.

Şimşek, Ö. F. (2007). Yapısal eşitlik modellemesine giriş temel ilkeler ve LISREL uygulamaları. Ankara: Ekinox

Tekbiyık, K. (2017). Impact of brand love on focal online and offline consumer behavior outcomes. Marmara Üniversitesi Sosyal Bilimler Enstitüsü İşletme Ana Bilim Dalı Yüksek Lisans Tezi. İstanbul.

Turgut, M.Ü. (2014), Marka Sevgisinin marka güveni, olumsuz bilgiye karşı direnç ve tekrar satın alma niyeti çerçevesinde incelenmesi. Y. Lisans Tezi, Hacettepe Üniversitesi.

Ünal, S. Ve Aydın, H. (2013). An investigation on the evaluation of the factors affecting brand love. Procedia-Social and Behavioral Sciences, 92, 76-85.

Valkenburg, P. M., \& Bujizen, M. (2005). Identifying determinants of young childeren's brand awareness: Television, parents, and peers. Applied Developmental Psychology, 26, 456-468.

Wallace, E., Buil, I., \& Chernatony, L.d. (2014). Consumer engagement with self-expressive brands: Brand love and WOM outcomes. Journal of Product \& Brand Management, 23(1), 33-42.

Yang, D. (2010). The effect of perceived quality and value in brand love, International Conference on Management and Service Science, Wuhan, China Date of Conference: 24-26 Aug. 2010 Date Added to IEEE Xplore: 16 September 2010.

Yıldız S. \& Tehci A. (2014). Ağızdan ağıza iletişimde müşteri tatmini ve müşteri sadakati ile mağaza imajı boyutları: ordu ilinde bir uygulama. Atatürk Üniversitesi Sosyal Bilimler Enstitüsü Dergisi, 18 (1), 441-460.

Yoo, B., \& Donthub, N. (1997). Developing and validating a multidimensional consumer-based brand equity scale. Journal of Business Research, 52(1), 1-14.

Yoo, B., Lee, S., \& Donthu, N. (2000). An examination of selected marketing mix elements and brand equity. Journal of the Academy of Marketing Science, 28(2), 195-211.

https://dictionary.cambridge.org/tr/s\%C3\%B6zl\%C3\%BCk/ingilizce/love Erişim Tarihi:01.03.2019

https://www.log.com.tr/dunyanin-en-cok-akilli-telefon-satan-5-markasi-2018-2-ceyrek-raporu/ Erişim:18.03.2019 